\title{
IDENTIFICATION OF IMPROVEMENTS FOR THE ENVIRONMENTAL MANAGEMENT SYSTEM IN COMPLIANCE WITH THE NBR ISO 14001 CERTIFICATE OF THE TOUR MACUCO SAFARI
}

\author{
Eloise Jacomellia \\ Eduardo César Dechechib \\ Manoela dos Santos Silveirac
}

\begin{abstract}
The company llha do Sol Agencia de Viagens Ltda. operates in the Iguaçu National Park in Foz do Iguaçu / PR for about 30 years offering boat trips that cover the rapids of the Iguaçu. This company had until 2010 a contract with IBAMA, which managed the Conservation Unit. As of 2010, through a new contract, the Chico Mendes Institute for Biodiversity Conservation - ICMBio starts to manage the National Parks, so the need specified in Public Tender arises that the company will have a Environmental Management - certified EMS.Thus, the Macuco Safari tour became NBR ISO 14001 certified in 2016, and like any organization certified by the standard, there are benefits and difficulties in maintaining the system.Intrinsic to the certification is the need for SAG improvements, in this sense, this experience reports the work developed with the objective of identifying improvements in the project's Environmental Management System, aiming at fulfilling the requirements of NBR ISO: 14001: 2015, For this purpose, Participant, Bibliographic and Documentary research was carried out based on the needs presented by the management team of the existing system in the company. At the end, lowinvestment, practical actions that have the potential to improve the EMS were identified, as well as giving visibility to the company, such as: holding meetings and training, exchanging unsustainable products for sustainable products, promoting environmental campaigns and publicizing company's EMS.
\end{abstract}

Keywords: NBR ISO 14001; Environmental management system; Environmental Certification; Macuco Safari. 


\section{INTRODUCTION}

Ecological tourism began to be discussed in Brazil in the 1970s, this discussion was driven by the economic development that had been occurring in the country and its environmental and social impact in all spheres (EMBRATUR, 2010). In the 80s, Ecotourism started to be studied by the Brazilian Tourism Institute - EMBRATUR, and gained strength in the 90s after the United Nations Conference on the Environment - ECO 92, held in 1992 in Rio de Janeiro / RJ where it type of tourism has gained greater notoriety worldwide (EMBRATUR, 2010). This Conference held other major milestones related to environmental business issues, such as promoting the creation of ISO Norms of the 14.000 series, focused on environmental issues (BARBOZA, 2001).

In September 1996 NBR ISO 14001 is published, it comprises internationally agreed standards that establish criteria for Environmental Management Systems. It is, therefore, a management model aimed at the viability of ecologically correct production and the induction of participatory culture that is based on organizational learning and disseminates environmental and sustainability values of resources (CAGNIN, 2000).

In this period (end of the 80's) the activities of the tour Macuco Safari, an enterprise focused on Ecotourism located in the premises of the Iguaçu $\mathrm{Na}$ tional Park in the city of Foz do Iguaçu / Pr.

At this time, the Iguaçu National Park was administered by the Brazilian Institute of IBAMA and the tour Macuco Safari had a contract to operate on the site offering its tour (two kilometers through the forest in a trailer, six hundred meters on foot and a boat trip through the rapids of the Iguaçu River until the fall of Three Musketeers at Iguazu Falls, during this period the project, for contractual and legal reasons, needed to take into account issues of reduction of environmental impacts because it is located within an Environmental Conservation Unit.

In 2007, the Chico Mendes Institute for Biodiversity Conservation is born, a subdivision of IBAMA that is responsible for managing all of Brazil's National Parks (ICMBIO, 2018). In the same period, PublicPrivate Partnerships began to take hold in the country, which take place through tenders, and with this new administration, National Parks started to incorporate this new trend.

Public-Private Partnerships are common in other countries, mainly in the European continent that have been in force for over twenty years, however, in Brazil it is a format that is in its initial phase (CINTRA, 2014), being legally instituted in the from the year 2004 with the institution of Federal Law No. 11,079, of December 30, 2004. This law provides that the public- private partnership is the administrative concession contract, in the sponsored or administrative modality, where the sponsored is the concession of public services or public works and the administrative is the service provision contract of which the Public Administration is the direct or indirect user, even if it involves the execution of a work or supply and installation of goods (PINTO, 2005).

From this it is established that to operate within the Iguaçu National Park, companies that provide some type of tour should participate in public tenders (bids). This happened with all the enterprises that currently operate in the Conservation Unit, the bids took place in 2009 starting in 2010 in force until 2020, if the winning companies in the bidding process properly fulfill their contracts, these can be extended by another five years.

Ilha do Sol Agencia de Viagens Ltda. - Macuco Safari, won the competition, and continued doing the tour before already offered. However, with new stricter contractual requirements in dealing with environmental issues, one of which is the implementation of an Environmental Management System certified by NBR ISO 14001 until the end of the contract. In view of the mandatory implementation of ISO 14001, Macuco Safari started its process of implementing ISO 14001, which at first was not completed, but which in 2015 gained priority, starting the certification process, with the elaboration of documentation and company to receive certification. After a year and a half of work, the company received the NBR ISO 14001 certification and the challenge became to maintain the certification.

Since, according to Lemos and Higuchi (2011), this regulation consists of guiding companies to adequately manage their environmental impacts. Obtaining this certification allows government regulators to demonstrate their commitment to environmental legality.

The authors Callembach et al (2004) summarize the aspects that motivate companies to accept responsibility for protecting the environment: (1) Sense of ecological responsibility, (2) Legal requirements (3) Protection of the company's interests, (4) Image, (5) Employee protection, (6) Market pressure, (7) Quality of life and (8) Profit. In this context, the implementation of the standard generates benefits such as: regulatory compliance, cost reduction, improvement of the company's reputation, qualification to enter the international market and reduction of waste (MACHADO et al, 2012).

In Brazil, the number of companies that adhere to the standard grows, with the hospitality sector being the sector that most adheres to the tourism sector (REVISTA HOTEIS, 2014). However, for Barbieri (2011), it is not enough just to implement an environmental policy in a company to obtain ISO 14001 certification, it is necessary to stimulate and mobilize the entire organization, both internally and externally so that there 
is really a concrete contribution with the environment. Implementing an Environmental Management System is considered difficult, but making it work properly is a greater challenge, since maintaining an environmental management system is highly costly (BARBIERI, 2011). In the case of NBR ISO 14001, there is a need to make improvements, even if small and punctual, in your EMS so that you can have a good assessment by the certifying body (ABNT NBR ISO 14001, 2015). In order to maintain NBR ISO 14001, compliance with the standard items is also essential, failure to comply with them generates Non-Conformities in the audit processes, which can result in the loss of certification (ABNT NBR ISO 14001, 2015).

Thus, with regard to the operation of NBR ISO 14001 by Macuco Safari, the company's difficulty in mobilizing employees to fill out control sheets for the Environmental Management System, which are fundamental to NBR ISO 14001: 2015, was notorious in the items: 5.3 Papers, responsibilities, and organizational authorities; 6.1.3 Legal and other requirements; 6.2.2 Action planning to achieve environmental objectives; 7.5.3 Control of documented information; 8.1 Operational planning and control; 9.1 Monitoring, measurement, analysis and evaluation and; 10.3 Continuous improvement. There was also difficulty in assessing the effectiveness of existing Programs, Objectives and Goals and in developing new ones, which is in line with the fulfillment of the items in NBR ISO 14001: 2015: 6.2 Environmental objectives and planning to achieve them; 6.2.1 Environmental objectives; 6.2.2 Action planning to achieve environmental objectives and; 10.3 Continuous improvement.

In view of the need to promote continuous improvement in the EMS, in order to comply with the requirements of ISO 14001 certification and the difficulties presented by the company Macuco Safari in the fulfillment of some items of the certification, there was an opportunity to assist the company in the identification of improvements in order to improve its process and also guarantee the fulfillment of the constitutive items of NBR ISO 14001. Thus, the objective of the intervention, which originated this report, was to identify improvements in the company's Environmental Management System aiming at the fulfillment of NBR requirements ISO 14001: 2015.

\section{METHODOLOGY}

In view of the objective of this research, it is characterized as nature as applied, since it is dedicated to the generation of knowledge to solve specific problems. With regard to the ends, it has an interventionist character, as the researcher is deeply involved with the object of study, characterizing this posture as a participatory methodology, since, in addition to acting as an intervening agent in the process, not only analyzing the data, but also acting on the object of study (OYADOMARI, DA SILVA, MENDONÇA NETO E RICCIO, 2014).

We opted for Participant Research, which according to Le Boterf (1984) in this type of research, the population involved aims to identify their problems, analyze them and seek the appropriate solutions. The choice for this approach was due to the fact that one of the authors, Eloise Jacomelli, was a collaborator of the enterprise for about four years and act as one of the members responsible for NBR ISO 14001 in the company.

For data collection, documentary research was carried out with the company's documents (GIL, 2010), in addition to meetings, together with the company's EMS management team, to better understand the needs of the organization and identify points for improvement. The research was conducted for a period of three months (from September 2018 to December 2019) following the steps shown in Chart 01.

Table 01: Research stages

\begin{tabular}{|c|c|c|c|}
\hline $\begin{array}{c}\text { Survey } \\
\text { of pri- } \\
\text { mary } \\
\text { data } \\
\text { using } \\
\text { docu- } \\
\text { ments }\end{array}$ & $\begin{array}{l}\text { Meeting } \\
\text { to un- } \\
\text { derstand } \\
\text { needs }\end{array}$ & $\begin{array}{l}\text { Mee- } \\
\text { ting to } \\
\text { present } \\
\text { propo- } \\
\text { sals }\end{array}$ & $\begin{array}{l}\text { Imple- } \\
\text { men } \\
\text { tation of } \\
\text { propo- } \\
\text { sals }\end{array}$ \\
\hline
\end{tabular}

Source: Elaborated by the authors

The research started by collecting data from the documentation provided by the company, helping to understand the context and understanding in NBR ISO 14001. Then, three meetings were held with the SGA management team in order to raise the difficulties encountered by the organization in maintenance of its environmental management system, for this purpose, it also used the experience of the author Eloise Jacomelli in the company. After identifying the difficulties, improvements were identified that could be applied on a daily basis, taking into account the company's needs and financial issues. These were presented and discussed in a meeting with the SGA management team.

\section{RESULTS}

The implementation of the work followed the meth- 
odological steps described and are presented in two stages, which together contribute to the objective of the work, namely:

1) Evaluate and propose ways to improve the collection of information necessary to monitor the data stipulated by the standard and;

2) Propose improvements to the continuous assessment system to guarantee certification.

Below are Tables 02 - Data collection, Proposals and Results of Objective 01 and Table 03 - Data collection, Proposals and Results of Objective 02, in these tables we seek to show in a simple and direct way what were the problems observed and raised, what were the best solutions according to the reality of the company found together with the management team of the SGA through meetings and what were the results achieved until the moment of carrying out this work.

From the realization of this, it is possible to observe that most of the actions did not generate financial costs or generated low costs, the implementation of the NBR ISO 14001 standard is sometimes considered to be of high financial cost, however, the standard itself shows that the company does not you need to make big investments, but promote environmental issues with the available resources.

Table 02: Survey of data, Proposals and Results of Objective 01

\section{OBJECTIVE 01:}

\begin{tabular}{|c|c|c|}
\hline $\begin{array}{l}\text { DATA RAISED RELATING TO THE } \\
\text { IDENTIFIED PROBLEM }\end{array}$ & $\begin{array}{c}\text { PROPOSALS FOR VIABLE IM- } \\
\text { PROVEMENTS PRESENTED TO } \\
\text { THE COMPANY }\end{array}$ & $\begin{array}{c}\text { RESULTS OBTAINED AFTER APPLI- } \\
\text { CATION OF THE PROPOSALS SUB- } \\
\text { MITTED }\end{array}$ \\
\hline $\begin{array}{l}\text { The company has } 50 \text { spreadsheets } \\
\text { of data records referring to the En- } \\
\text { vironmental Management System } \\
\text { and; } \\
\text { Of the total spreadsheets, } 17 \text { are } \\
\text { filled out regularly, of which } 12 \text { are } \\
\text { the responsibility of the Biology } \\
\text { sector, this sector is responsible for } \\
\text { the Environmental Management } \\
\text { System, all the others }(38 \text { spread- } \\
\text { sheets) are the responsibility of the } \\
\text { other sectors of the company, or } \\
\text { are controls that must be complet- } \\
\text { ed by all employees, such as: Acci- } \\
\text { dents and Incidents, Fauna Visuali- } \\
\text { zation and Non-Conformities and; } \\
\text { Spreadsheets Filled Regularly: } 17 ; \\
\text { Spreadsheets Filled Irregularly: } 23 \\
\text { e; Unused spreadsheets: } 10 \text {. }\end{array}$ & $\begin{array}{l}\text { Verification of the usefulness } \\
\text { and validity of all existing } \\
\text { spreadsheets in the system; } \\
\text { Correction / deletion of expend- } \\
\text { able items from spreadsheets; } \\
\text { Holding meetings with the head } \\
\text { of sector; } \\
\text { Conducting general meetings } \\
\text { and;i; } \\
\text { Promotion of gymkhana among } \\
\text { employees. }\end{array}$ & $\begin{array}{l}\text { Exclusion of } 03 \text { spreadsheets and } \\
\text { correction of } 02 \text { spreadsheets from } \\
\text { the Environmental Management } \\
\text { System, as they are no longer use- } \\
\text { ful to the system, thus becoming } \\
\text { obsolete documents, which must } \\
\text { be discarded according to NBR ISO } \\
14001: 2015 ; \\
\text { Sectoral meetings were held, to } \\
\text { increase the number of spread- } \\
\text { sheets, and it was recommended to } \\
\text { hold general meetings at least } \\
\text { once a month to request such fill- } \\
\text { ings, since after the meetings there } \\
\text { was an increase in such activity; } \\
\text { Disclosure via the wall (the most } \\
\text { efficient method identified due to } \\
\text { the cost and reach of all employ- } \\
\text { ees) available to employees from a } \\
\text { ranking of filling spreadsheets with } \\
\text { monthly prizes for those who most } \\
\text { fill them. After the disclosure, em- } \\
\text { ployees began to fill in the spread- } \\
\text { sheets disclosed more frequently, } \\
\text { as identified in the two months } \\
\text { after the implementation of the } \\
\text { method. }\end{array}$ \\
\hline
\end{tabular}




\begin{tabular}{|c|c|c|}
\hline \multicolumn{3}{|c|}{ OBJECTIVE 02: } \\
\hline $\begin{array}{l}\text { DATA RAISED RELATING TO THE } \\
\text { IDENTIFIED PROBLEM }\end{array}$ & $\begin{array}{c}\text { PROPOSALS FOR VIABLE IM- } \\
\text { PROVEMENTS PRESENTED TO } \\
\text { THE COMPANY }\end{array}$ & $\begin{array}{l}\text { RESULTS OBTAINED AFTER } \\
\text { APPLICATION OF THE PRO- } \\
\text { POSALS SUBMITTED }\end{array}$ \\
\hline $\begin{array}{l}\text { The company has 09 Programs, Ob- } \\
\text { jectives and Goals, which are: Water } \\
\text { Saving, Electric Energy Saving, Re- } \\
\text { ducing the Use of Sulfite Paper, Re- } \\
\text { ducing the Viewing of Surrounding } \\
\text { Residues, Reducing the Viewing of } \\
\text { Exotic Flora Species, Increasing Use } \\
\text { of Reused Water, Increased Filling in } \\
\text { the Animal Viewing Worksheet, } \\
\text { Monitoring Visitor Assessment in } \\
\text { the Environmental Conservation } \\
\text { Tract on the Macuco Safari Tour } \\
\text { and Monitoring Water Quality for } \\
\text { Human Consumption; } \\
\text { There are fluctuations in meeting } \\
\text { the reduction targets compared to } \\
\text { the years } 2017 / 2018 \text { in the pro- } \\
\text { grams: Water Savings, Electricity } \\
\text { Savings, Reduction of Sulfite Paper } \\
\text { Use. However, they are not big } \\
\text { swings; } \\
\text { The results of the Programs, Objec- } \\
\text { tives and Goals must be monitored } \\
\text { month by month, so that the com- } \\
\text { pany seeks ways to improve the } \\
\text { negative results in this, however, } \\
\text { such control established by the or- } \\
\text { ganization has not been fulfilled, } \\
\text { usually due to the lack of initiative } \\
\text { by the employees or not attendance } \\
\text { of employees at meetings and; } \\
\text { The current Programs, Objectives } \\
\text { and Goals must be updated, being } \\
\text { created in accordance with the } \\
\text { guidelines of NBR ISO } 14001: 2015 \\
\text { and with a document prepared by } \\
\text { the company. }\end{array}$ & $\begin{array}{l}\text { To continuously improve the Pro- } \\
\text { grams, Objectives and Goals } \\
\text { when updating them, add the } \\
\text { program: Environmental Educa- } \\
\text { tion for Visitors (labels with envi- } \\
\text { ronmental phrases on products } \\
\text { sold in souvenir shops, exchange } \\
\text { of plastic bags from souvenir } \\
\text { stores for paper bags with } \\
\text { phrases and images relating to } \\
\text { the environment, exchange of } \\
\text { plastic cups from souvenir shops } \\
\text { for paper cups and an education- } \\
\text { al banner on the store's deck re- } \\
\text { served for food tables) and; } \\
\text { To properly analyze the results of } \\
\text { the Programs, Objectives and } \\
\text { Goals, establish a fixed monthly } \\
\text { date and time, and hold the } \\
\text { meeting even if a member of the } \\
\text { Biology sector team is not present } \\
\text { at the predetermined date and } \\
\text { time. }\end{array}$ & $\begin{array}{l}\text { Creation of the Environmental } \\
\text { Education Program and Promo- } \\
\text { tion of Activities on Commemo- } \\
\text { rative Dates. } \\
\text { Labels with educational phrases } \\
\text { in the goods sold in the shop } \\
\text { (Realized); } \\
\text { Exchange of plastic bags for } \\
\text { recycled paper bags with animal } \\
\text { prints that can be seen on the } \\
\text { Macuco Safari tour (Budget / } \\
\text { Estimated for 2019); } \\
\text { Educational banner on the Cen- } \\
\text { tral Store Deck, not feeding wild } \\
\text { animals (Budget / Expected for } \\
\text { 2019); } \\
\text { Exchange of disposable cups in } \\
\text { stores for recycled paper cups } \\
\text { (Budget / Planned for } 2019 \text { ); } \\
\text { Television for displaying envi- } \\
\text { ronmental information to be } \\
\text { available at the reception of the } \\
\text { Macuco Safari tour (Budget / } \\
\text { Estimated for 2019); } \\
\text { Creation of the Activities Pro- } \\
\text { motion Program on Commemo- } \\
\text { rative Dates: Water Day; Envi- } \\
\text { ronment Week; Arbor Day and; } \\
\text { Rio Day (this program started in } \\
\text { November, in celebration of the } \\
\text { water day, the company pro- } \\
\text { moted a river cleaning in part- } \\
\text { nership with Centro Universitári- } \\
\text { oUniamérica, inviting Biology } \\
\text { students to participate in the } \\
\text { cleaning effort, as the action } \\
\text { was registered and shown by } \\
\text { the regional television program } \\
\text { Caminhos do Oeste and ap- } \\
\text { pears on the YouTube platform; } \\
\text { A fixed monthly day and time } \\
\text { has been established for the } \\
\text { meeting regarding the follow- } \\
\text { up of matters related to the } \\
\text { Macuco Integrated System } \\
\text { SIM (NBR ISO } 14001: 2015 \text { and } \\
\text { NBR IsO 21001: 2014). }\end{array}$ \\
\hline
\end{tabular}


From the reading of the tables, it is observed that, in general, the company has been very happy in the operation of the Environmental Management System certified by NBR ISO 14001 in the implanted enterprise, since this has worked in an adequate way to the guidelines of the standard and the one proposed by company, with the need for only minor adjustments and daily corrections.

\section{Final Considerations}

The accomplishment of this work provided both academic and professional development, since it united theory with practice.

Opportunities like this and others promoted by the Professional Master's course in Technologies, Management and Sustainability at the State University of Western Paraná - Unioeste, Campos do Foz do Iguaçu throughout the academic period are of great relevance for students, as they generate interaction between the academy and local companies, expanding horizons, where it can be seen that not everything works the same way for all companies, since each one has singularities, but that there are methods that can be applied for each one, helping to improve processes, procedures within others of the same.

It also provides a scientific contribution to tourismoriented enterprises that are interested in developing EMS.

\section{REFERENCES}

ASSOCIAÇÃO BRASILEIRA DE NORMAS - ABNT. Normas da Série ISO 14000. NBR ISO 14001. Rio de Janeiro. 2015.

BARBIERI, J. C. Gestão Ambiental Empresarial: conceitos, modelos e instrumentos. São Paulo: Ed. Saraiva. 2011.

BARBOZA, E. M. F. Rotulagem Ambiental: Rótulos ambientais e Análise do ciclo de vida (ACV). Brasília: IBICT.2001.

BRASIL, Ministério do Turismo. Livreto Ecoturismo. Fonte: Secretaria Nacional de Políticas de Turismo - Embratur. 2010. Disponível em: < http://www.turismo.gov.br/ sites/default/turismo/o_ministerio/publicacoes/ downloads publicacoes .pdf $>$. Acesso em: 25 de março de 2019 .

CAGNIN, C. H. Fatores relevantes na implantação de um Sistema de Gestão Ambiental com base na norma ISO 14001. Dissertação (Mestrado em Engenharia de Produção) - Universidade Federal de Santa Catarina, Florianópolis.2000
CALLENBACH, E. CAPRA, F: GOLDMAN, L. LUTZ, R. \& MARBURG, S. CASTRO, Diego; CASTILHO, Selene; MIRAN$\mathrm{DA}$, Silvia. A rotulagem ambiental no contexto de comercio internacional. Esalp/USP, Ribeirão Preto, SP, 2004.

CANDIOTTO, L. Z. P. Considerações sobre o conceito de turismo sustentável. Revista Formação, n. 16, v. 1. Presidente Prudente, p. 48 - 59. 2009.

CINTRA, M. Modelagem de PPPs: pré-requisitos fundamentais e suas implicações. Revista FGV Projetos, Ano 9, $\mathrm{N}^{\mathrm{O}} 23.2014$

EMBRATUR, Instituto Brasileiro de Turismo. Hotelaria. Disponível em: <http://www.embratur.gov.br/>. Acesso em: dezembro de 2018. 2010.

GIL, A. C. Como elaborar projetos de pesquisa. 5a ed. São Paulo: Atlas.2010.

ICMBIO -Instituto Chico Mendes de Conservação da Biodiversidade, 2018. Disponível em:<http:// www.icmbio.gov.br/portal/licitacoes1/editais? $\mathrm{id}=8629$ :editaisdiversos-2017 >. Acesso em: 22 de março de 2019.

LE BOTERF, Guy. (1984). Pesquisa participante: Propostas e reflexões metodológicas. In: Brandão Carlos Henrique. et. al. Repensando a pesquisa participante. São Paulo: Brasiliense.

LEMOS, Sônia Maria; HIGUCHI, Maria Inês Gasparetto. Compromisso Socioambiental e Vulnerabilidade. Ambiente \& Sociedade, Campinas - SP, v. 14, n. 2, p.123138, jul. 2011.

MACHADO, Lisiane; SILVA, Lisiane Vasconcellos da. A Pesquisa Acadêmica no Contexto Internacional - Uma Análise Exploratória dos Trabalhos de Conclusão de 161 Curso, desenvolvidos na Graduação em Administracão com Habilitação em Comérçio Exterior. em uma Universidade do Sul do País. XXXI Enanpad, Rio de Janeiro - RJ, set. 2007.

MARCONI, M. de A. \& LAKATOS, E. M. Metodologia cientifica: ciência e conhecimento científico, métodos científicos, teoria, hipóteses e variáveis. 5. ed. São Paulo: Atlas.2007.

OYADOMARI, J.C.T da SILVA, P. L, MENDONCA NETO, O R \& RICCIO, E. L. (2014). Pesquisa intervencionista: um ensaio sobre as oportunidades e riscos para pesquisa brasileira em contabilidade gerencial. Advances in Scientific and Applied Accounting, v.7, n.2, 244-265.

PINTO, José Emilio Nunes. A percepção de risco nas Parcerias Público-Privadas e a lei 11.079/2004 e seus mitigantes Jus Navegandi, Teresina. a.9, n. 549, 7 jan. 2005. Disponível em http://jus2.uol.com.br/ doutrina/ texto.asp?id=6156 Acesso em dezembro de 2018 .

REVISTA HOTÉIS. Cresce número de hotéis que investem em ações ambientais. Disponível em: <http:// www.revistahoteis.com.br/materias/7-area-/1614Cresce-numero-de-hoteis-queinvestem-em-acoesambientais >. 2014. 